Sains Malaysiana 49(3)(2020): 603-611

http://dx.doi.org/10.17576/jsm-2020-4903-15

\title{
Effects of Plant Oligosaccharides Derived from Dragon Fruit on Gut Microbiota in Proximal and Distal Colon of Mice
}

(Kesan Tumbuhan Oligosakarida yang Diambil daripada Buah Naga pada Mikrobiota Usus dalam Kolon Proksi dan Distal Tikus)

\author{
SARANya PEERAKIETKhajorn*, Nilobon JeAnMard, PAPATSORn ChUENPANitKit, SAKENA K-DA, \\ KANRAWEE BANNOB \& PisSARED KhUITUAN
}

\begin{abstract}
Prebiotic oligosaccharides are used as supplements to improve colon health. Oligosaccharides derived from dragon fruit (DFO) are a mixture of fructo-oligosaccharides (FOS), and have prebiotic properties that increase beneficial bacteria in vitro. This study aimed to investigate changes in gut microbiota in the colon of mice fed a diet supplemented with DFO. Treatment groups were fed 100, 500, and $1000 \mathrm{mg} / \mathrm{kg}$ of DFO, $1000 \mathrm{mg} / \mathrm{kg} \mathrm{FOS} \mathrm{and} \mathrm{distilled} \mathrm{water.} \mathrm{The}$ results showed that DFO did not change the body weight of mice, but altered microbiota in the proximal and distal colon. Populations of Blautia, Parabacteroides, and Bacteroides were among the highest proportions of bacteria represented after all treatments. Lactobacillus was also found in the proximal and distal colon. Moreover, qPCR results showed that Bifidobacteria increased in the distal colon of mice treated with 100 and $1000 \mathrm{mg} / \mathrm{kg}$ DFO for 14 days, while Lactobacilli increased in the proximal colon of mice treated with $500 \mathrm{mg} / \mathrm{kg} \mathrm{DFO} \mathrm{for} 7$ days. In contrast, Enterococci decreased in the proximal colon of mice that were given 100, 500, and $1000 \mathrm{mg} / \mathrm{kg}$ of DFO and $1000 \mathrm{mg} /$ $\mathrm{kg}$ of FOS for 14 days. These results suggested that DFO is capable of increasing populations of beneficial bacteria while decreasing populations of some other bacteria.
\end{abstract}

Keywords: Colon; dragon fruit; gut microbiota; prebiotic oligosaccharides

ABSTRAK

Oligosakarida prebiotik digunakan sebagai suplemen untuk menambahbaik kesihatan kolon. Oligosakarida yang diambil daripada buah naga (DFO) adalah campuran frukto-oligosakarida (FOS) dan mempunyai sifat prebiotik yang meningkatkan bakteria berfaedah secara in vitro. Kajian ini bertujuan untuk mengkaji perubahan dalam mikrobiota usus pada kolon tikus diberi makan diet disuplementasi dengan DFO. Kumpulan rawatan diberi makan 100, 500 dan $1000 \mathrm{mg} / \mathrm{kg}$ DFO, $1000 \mathrm{mg} / \mathrm{kg}$ FOS dan air suling. Keputusan menunjukkan DFO tidak mengubah berat tikut tetapi meminda mikrobiota pada proksimal dan kolon distal. Populasi Blautia, Parabacteroides dan Bacteroides adalah antara perkadaran tertinggi bakteria selepas rawatan. Lactobacillus juga ditemui pada proksimal dan kolon distal. Tambahan lagi, keputusan qPCR menunjukkan bahawaa Bifidobacteria meningkat dalam kolon distal tikus dirawat dengan 100 dan $1000 \mathrm{mg} / \mathrm{kg}$ DFO untuk 14 hari, manakala Lactobacilli meningkat dalam kolon distal tikus dirawat dengan $500 \mathrm{mg} / \mathrm{kg}$ DFO untuk 7 hari. Secara kontra, Enterococci menurun dalam kolon distal tikus yang diberi makan 100, 500 dan 1000 mg/kg DFO serta 1000 mg/kg FOS untuk 14 hari. Keputusan ini menunjukkan bahawa DFO berupaya untuk meningkatkan populasi bakteria berfaedah sambil menurunkan populasi bakteria lain.

Kata kunci: Buah naga; kolon; mikrobiota usus; oligosakarida prebiotik

\section{INTRODUCTION}

Prebiotics are non-digestible nutrients, such as inulin, fructo-oligosaccharide (FOS), isomalto-oligosaccharide, xylo-oligosaccharide, lactulose, and galactooligosaccharide (GOS), which can be found in natural foods like chicory, agave, artichoke, grains, milk, and dragon fruit (Gibson \& Rastall 2006; Wichienchot et al. 2010). Prebiotics increase the growth of bifidobacteria and lactobacilli in the human intestine and provide health benefits to both humans and animals as they affect the composition of microbiota in the gut and improve the gastrointestinal system of hosts (Binn 2013; Femia et al.
2010; Gibson et al. 2010; Mandal et al. 2009; SabaterMolina et al. 2009; Vamanu \& Vamanu 2010; Xu et al. 2009; Yeo \& Liong 2010). Furthermore, prebiotics are able to prevent infectious diarrhea, antibiotic-associated diarrhea, traveler's diarrhea, irritable bowel syndrome (IBS) and colitis, and also reduce cholesterol levels (Binn 2013; Guarner \& Malagelada 2003; Patel \& Goyal 2012).

Prebiotics have been used as supplements in animal food. A previous study showed that mannan-oligosaccharide increased the villus length of the duodenum and jejunum as well as the crypt depth of the duodenum and ileum of broiler chickens (Pelicano et al. 2005). Moreover, the 
combination of chicory prebiotic and Enterococcus faecium could enhance growth and increase the length of the villus and crypt of broiler chickens (Awad et al. 2008). In addition, oligosaccharides extracted from vegetables and fruits are useful prebiotics that effectively promote beneficial bacteria and inhibit harmful bacteria (Gibson \& Roberfroid 1995; Thammarutwasik et al. 2009; Wichienchot et al. 2010).

The dragon fruit (Hylocereus undatus (Haw.)) is a nutrient-rich fruit that contains high levels of beta-carotene, lycopene, and vitamin E (Charoensiri et al. 2009). The unsaturated fatty acids in oil extracted from dragon fruit seeds is composed of about $50 \%$ essential fatty acids (48 $\%$ linoleic acid (C18:2), and 1.5\% linolenic acid (C18:3)) (Ariffin et al. 2008). Glucose, fructose, and oligosaccharides are also present in dragon fruit (Wichienchot et al. 2010). Powdered dragon fruit oligosaccharide (DFO) mainly consists of fructo-oligosaccharide (DP 2 - 5) and fructose (Wichienchot \& Pansai 2013). An in vitro study showed that although DFO was not digested by human gastric juices, it could increase the growth of Lactobacillus and Bifidobacterium while reducing the growth of Bacteroides and Clostridium (Dasaesamoh et al. 2016a; Wichienchot et al. 2010). In addition, a fecal fermentation experiment showed that increased levels of short chain fatty acids inhibited the growth of carcinogenic colon cells (Caco-2), thus DFO decreased the risk of colon cancer (Dasaesamoh et al. 2016a). However, the effects of DFO on the composition of gut microbiota in the colon of healthy mice are still unknown. This paper presents an in vivo study conducted to identify changes in gut microbiota in mice treated with DFO.

\section{MATERIALS AND METHODS}

\section{ANIMALS}

Inbred mice (strain BALB/cMlac, 5 weeks old and weighing $20-21 \mathrm{~g}$ ) were obtained from the National Laboratory Animal Center, Mahidol University, Thailand. All mice were reared under controlled conditions (temperature $23-25{ }^{\circ} \mathrm{C}$, relative humidity $50-55 \%$ and 12:12 h light/dark cycle) at the Southern Laboratory Animal Facility, Prince of Songkla University, Thailand. Mice were given commercial animal food (S.W.T.,
Thailand) and free access to filtered water. The experimental protocol was approved by the Institutional Animal Care and Use Committee of Prince of Songkla University (project license number: MOE 0521.11/1410 Ref. 16/2016).

\section{EXTRACTION OF OLIGOSACCHARIDES FROM DRAGON FRUITS}

DFO was supplied by a research group at the Interdisciplinary Graduate School of Nutraceutical and Functional Food, Prince of Songkla University. White-fleshed dragon fruit was extracted using $80 \%$ ethanol at ambient temperature $\left(28 \pm 2{ }^{\circ} \mathrm{C}\right)$. Ethanol was then removed by distillation using a rotary evaporator operating at $175 \mathrm{mbar}, 60^{\circ} \mathrm{C}$, and 45 $\mathrm{rpm}$. The dragon fruit extract was diluted 1:1 with distilled water, then redistilled to remove residual ethanol, and adjusted to $20^{\circ}$ Brix. Glucose and fructose were removed from the extract by yeast fermentation at room temperature $\left(28 \pm 2{ }^{\circ} \mathrm{C}\right)$ for $48 \mathrm{~h}$ with a $5 \%(\mathrm{v} / \mathrm{v})$ inoculum of Saccharomyces cerevisiae strain BCC 12652. The fermented broth was filtered through cheesecloth to remove suspended solids $(>500 \mu \mathrm{m})$ including yeast pellets. The filtered broth was centrifuged at $10,000 \times \mathrm{g}$ at $4{ }^{\circ} \mathrm{C}$ to completely separate small solid particles and yeast cell debris. The purified supernatant was concentrated by rotary evaporator and spray dried to obtain DFO powder (Dasaesamoh et al. 2016b; Wichienchot et al. 2010). The chemical composition and oligosaccharide content of the obtained DFO powder were analyzed by AOAC (The Association of Analytical Chemists) method and HPAECPAD, respectively (Table 1) (Wichienchot \& Pansai 2013). The dried DFO powder was kept at $-20{ }^{\circ} \mathrm{C}$ until use.

\section{DFO TREATMENT AND COLLECTION OF GUT CONTENTS}

Fifty mice were seperated into a 7-day treatment group of 25 individuals and a 14-day treatment group of 25 individuals. Both groups were then divided into five subgroups of five individuals which were all given access to commercial food. Additionally, the diet of each treatment group of five mice was supplemented differently by the administration (P.O.) of distilled water (DW), $100 \mathrm{mg} / \mathrm{kg}$ of DFO (DFO100), $500 \mathrm{mg} / \mathrm{kg}$ of DFO (DFO500), 1000 $\mathrm{mg} / \mathrm{kg}$ of DFO (DFO1000), or $1000 \mathrm{mg} / \mathrm{kg}$ of FOS

TABLE 1. Chemical composition and oligosaccharide content of DFO powder (Wichienchot \& Pansai 2013)

\begin{tabular}{lc}
\hline Composition & Amount in $100 \mathrm{~g}$ powder $(\mathrm{g})$ \\
\hline Carbohydrate & 91.6 \\
$\quad$ Oligosaccharide (DP2-5) & 71.5 \\
Fructose & 20.1 \\
Protein & 1.8 \\
Fat & 0.1 \\
Ash & 2.2 \\
Moisture & 4.3 \\
\hline
\end{tabular}


(FOS1000). FOS was used as a positive control at the same concentration used in a previous study that changed the populations of Enterococci, Enterobacteriaceae, Bifidobacteria and Lactobacilli in the cecum of mice (Pan et al. 2009). Body weight was recorded every day prior to the start of the experiment. Body weight change was calculated based on the change of body weight before and after the treatments. At the end of treatments, mice were anesthetized by intraperitoneal injection of $70 \mathrm{mg} / \mathrm{kg}$ thiopental sodium (Anesthal ${ }^{\circledR}$ ), then the abdominal cavity was dissected and the entire colon was removed. The mice were then immediately euthanized. The removed colons were sectioned into proximal ( $3 \mathrm{~cm}$ distal to the cecum) and distal $(3 \mathrm{~cm}$ proximal to the rectum) segments. Gut contents were collected in autoclaved microcentrifuge tubes and kept at $-80{ }^{\circ} \mathrm{C}$ until use.

\section{DNA EXTRACTION, PCR, AND ILLUMINA MISEQ}

Before extraction of DNA, collected gut contents were homogenized in $200 \mu \mathrm{L}$ Buffer A solution $(100 \mathrm{mM}$ Tris-HCl, $100 \mathrm{mM}$ ethylenediaminetetraacetic acid [EDTA], $100 \mathrm{mM} \mathrm{NaCl}$, and $0.5 \%$ sodium dodecyl sulfate [SDS], pH 7.5) in a $1.5 \mathrm{~mL}$ tube and incubated at $65{ }^{\circ} \mathrm{C}$ for $30 \mathrm{~min}$. The incubated homogenate was then mixed with $400 \mu \mathrm{L}$ of $\mathrm{LiCl} / \mathrm{KAc}$ solution $(5 \mathrm{M}$ potassium acetate: $6 \mathrm{M}$ lithium chloride $=1: 2.5$ ), incubated on ice for $10 \mathrm{~min}$ and centrifuged for $15 \mathrm{~min}$ at $15000 \mathrm{rpm}$. After centrifugation, $500 \mu \mathrm{L}$ of the supernatant was transferred to a new tube, mixed with $300 \mu \mathrm{L}$ isopropanol, and centrifuged for $15 \mathrm{~min}$ at $15,000 \mathrm{rpm}$. Lastly, the supernatant was removed, the precipitate was washed with $70 \%$ ethanol, dried, and resuspended in $100 \mathrm{uL}$ of MilliQ. All DNA samples were kept at $-30{ }^{\circ} \mathrm{C}$ until used to amplify the $16 \mathrm{~S}$ rRNA gene.

The V3-V4 hypervariable region of the bacterial $16 \mathrm{~S}$ rRNA gene was amplified using $2 \times$ KAPA HiFiHotStart Ready mix DNA polymerase (Kapa Biosystems Ltd., London, UK) and primers with overhang adapter sequences (forward primer: 5'-TCGTCGGCAGCGTCAGATGTGTA TAAGAGACAGCCTACGGGNGGCWGCAG-3', and reverse primer: GTCTCGTGGGCTCGGAGATGTGT ATAAGAGACAGGACTACHVGGGTATCTAATCC-3') (Johnston et al. 2017). Cycle conditions were $3 \mathrm{~min}$ at $95^{\circ} \mathrm{C}$ followed by 25 three-temperature cycles $\left(30 \mathrm{~s}\right.$ at $95^{\circ} \mathrm{C}, 30$ $\mathrm{s}$ at $55^{\circ} \mathrm{C}$, and $3 \mathrm{~min}$ at $72{ }^{\circ} \mathrm{C}$ ), then a final extension of $72{ }^{\circ} \mathrm{C}$ for $5 \mathrm{~min}$. Libraries were purified using AMPure XP beads (LABPLAN; Naas, Ireland) in accordance with the Illumina $16 \mathrm{~S}$ metagenomics sequencing library protocol. Dual Indices from the Illumina Nextera XT index kit (Illumina, San Diego, USA) were added to the target amplicons in the second PCR using $2 \times$ KAPA HiFi HotStart Ready mix DNA polymerase (Kapa Biosystems Ltd., London, UK) under the following conditions: $3 \mathrm{~min}$ at 95 ${ }^{\circ} \mathrm{C}$ followed by 9 three-temperature cycles $\left(30 \mathrm{~s}\right.$ at $95^{\circ} \mathrm{C}$, $30 \mathrm{~s}$ at $55^{\circ} \mathrm{C}$ and $3 \mathrm{~min}$ at $72^{\circ} \mathrm{C}$ ), then a final extension of $72{ }^{\circ} \mathrm{C}$ for $5 \mathrm{~min}$. Libraries were purified using AMPure XP beads (LABPLAN; Naas, Ireland).
The barcoded amplicon libraries were combined into a single pool. The library pool was diluted and denaturated according to the Illumina Miseq library preparation guide. Sequencing was conducted on the Illumina Miseq using the 600 cycle Miseq reagent kit (version 3), and produced paired 301-bp reads. All sequencing data produced in this study were deposited in the NCBI SRA repository and are available via series accession number PRJNA516321.

\section{METAGENOMIC ANALYSIS}

Paired-end read sequences generated from Illumina Miseq were processed using Illumina 16S Metagenomics (version 1.0.1) workflow in Base Space-Illumina (https:// basespace.illumina.com/). Each read was blasted against the Illumina-curated version of the Greengenes database (greengenes.secondgenome.com/downloads/ database/13_5) to determine the operational taxonomic units (OTUs) which corresponded to the 16S rRNA gene sequences. Taxa which did not conform enough to further classification, such as 'unclassified at Kingdom level' and 'Viruses', were excluded from subsequent diversity analysis. OTU richness, Shannon-Weiner and Simpson diversity indices and evenness based on genera of bacteria were calculated.

\section{QUANTITATIVE POLYMERASE CHAIN REACTION (qPCR)}

qPCR of bacterial 16S rDNA of total bacteria, Lactobacilli, Bifidobacteria, and Enterococci was performed using a qPCR machine (LineGene 9600 Plus, Bioer, China) and SensiFAST SYBR No-ROX Kit (Bioline). PCR amplification protocols used the following primer sets to determine the total number of bacteria (forward 5'-AGACACGGTCCAGACTCCTAC-3'; reverse 5'-TTTACGGCGTGGACTACCAG-3'), the total number of Lactobacilli (FW 5'-CGATGAGTGCTAGGTGTTGGA -3'; RV 5'-CAAGATGTCAAGACCTGGTAAG-3'), the total number of Bifidobacteria (LM26 5'-GATTCT GGCTCAGGATGAACGC-3'; Bif228 5'-CTGATAGG ACGCGACCCCAT-3'), and the total number of Enterococci (ECF 5'-AGAAATTCCAAACGAACTTG-3'; ECR 5'-CAGTGCTCTACCTCCATCATT-3'). All reactions took place under the same conditions: $3 \mathrm{~min}$ at $95^{\circ} \mathrm{C}$, and 40 two-temperature cycles $\left(5 \mathrm{~s}\right.$ at $95^{\circ} \mathrm{C}$ and 30 $\mathrm{s}$ at $60{ }^{\circ} \mathrm{C}$ ) (Fu et al. 2006; He \& Jiang 2005; Kaufmann et al. 1997; Matsuki et al. 2004; Peerakietkhajorn et al. 2015).

\section{STATISTICAL ANALYSIS}

Daily body weight, body weight change, and amount of bacteria were presented as means \pm standard error (SE). All data were tested with one-way ANOVA followed by Tukey's honestly significant difference test at $p<0.05$ to compare with the control group. The statistical analyses were performed using the $\mathrm{R}$ statistical program $\mathrm{R}$ 3.5.2 (The R Core Team 2013). 


\section{RESULTS}

EFFECTS OF DFO ON BODY WEIGHT OF MICE

The initial body weight of mice was $20.0 \pm 0.0 \mathrm{~g}$. At the end of the 7 day-treatments, body weight of all groups had increased to $22.2 \pm 0.7$ (DW), 23.6 \pm 1.1 (DFO100), 24.4 \pm 0.8 (DFO500), $22.2 \pm 0.4$ (DFO1000), and $23.8 \pm 0.7 \mathrm{~g}$ (FOS1000). At the end of the 14-day treatments, body weight of all groups had increased to $24.0 \pm 1.0$ (DW), $22.0 \pm 1.2$ (DFO100), $24.0 \pm 1.0$ (DFO500), $24 \pm 1.0$ (DFO1000), and 24.0 $\pm 1.0 \mathrm{~g}$ (FOS1000). The body weight of mice in 7- and 14-day treatments was not significantly different among all treatments $(p>0.05$, Figure $1(\mathrm{~A})$ and 1(B)). Their body weight changes were also not significantly different ( $p>0.05$, Figure 1(C)).

\section{EFFECTS OF DFO ON GUT MICROBIOTA IN PROXIMAL AND DISTAL COLON}

A total of 6,268,538 raw data reads were generated from Illumina Miseq. About 5,683,885 high-quality reads remained after trimming and filtering. The range of highquality reads per sample was 218,376 to 456,208 .
The total OTU richness at the genus level in the proximal colon of treated mice was estimated from 16S metagenomics results. In the 7-day treatment groups DW, DFO100, DFO500, DFO1000, and FOS1000, the OTU richness were $277,270,303,280$, and 284 , respectively (Table 1). The dominant bacteria included Blautia (19-31 \%), Parabacteroides (22 - $31 \%$ ), Bacteroides (7 - $13 \%$ ) and Lactobacillus (2 - $14 \%$ ) (Figure 2(A)). ShannonWiener and Simpson diversity indices were similar in all 7-day treatments groups (2.376 - 2.513 and $0.143-0.169$, respectively). The range of evenness of bacteria in the proximal colon at the end of 7-day treatments was from 0.416 to 0.447 (Table 2).

The bacterial composition in the proximal colon at the end of the 14-day treatments was similar to that of the 7 -day treatments. The dominant bacteria included Blautia (15 - $25 \%)$, Parabacteroides (13 - $21 \%)$, Bacteroides (5 - $10 \%$ ), and Lactobacillus (1 - $8 \%$ ) (Figure 2(B)). OTU richness at the genus level in the proximal colon of mice from the 14-day treatment groups DW, DFO100, DFO500, DFO1000 and FOS 1000 were 277, 283, 267, 279, and 258 OTUs, respectively (Table 2). The Shannon-Wiener and Simpson diversity indices for these groups ranged from
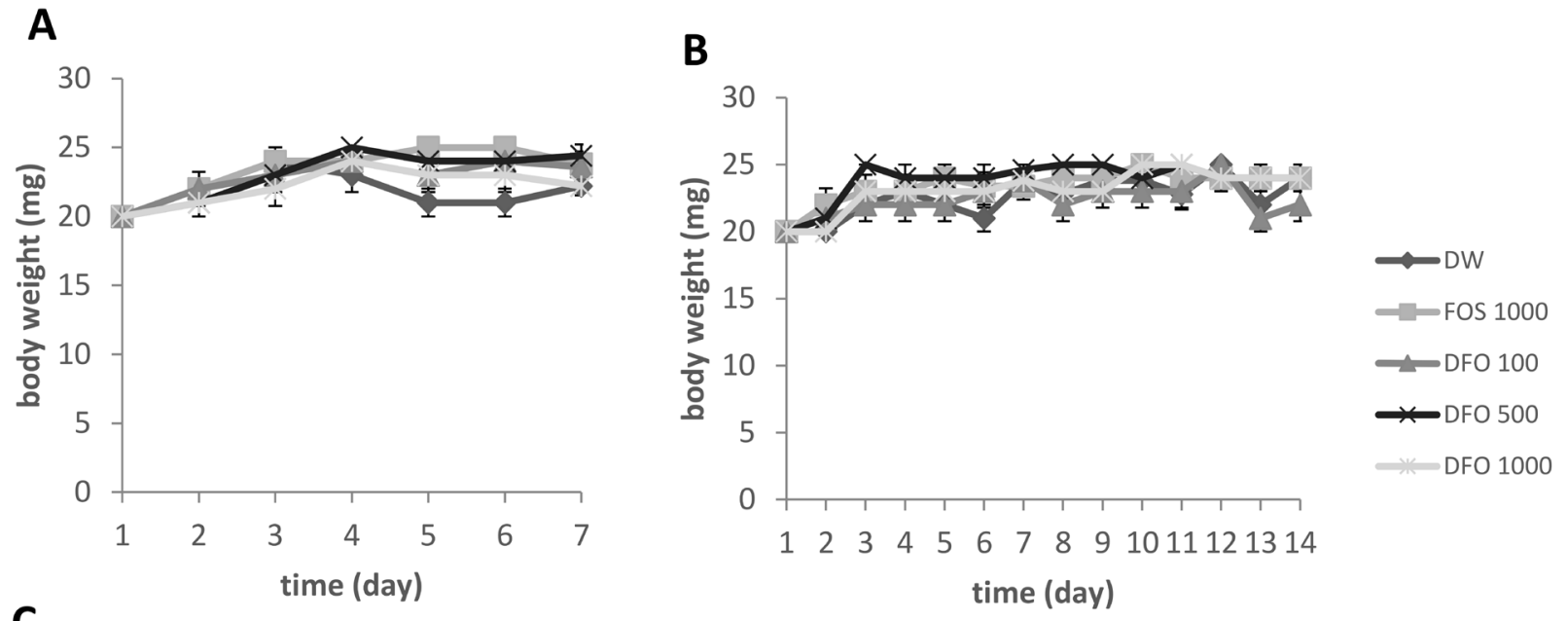

C

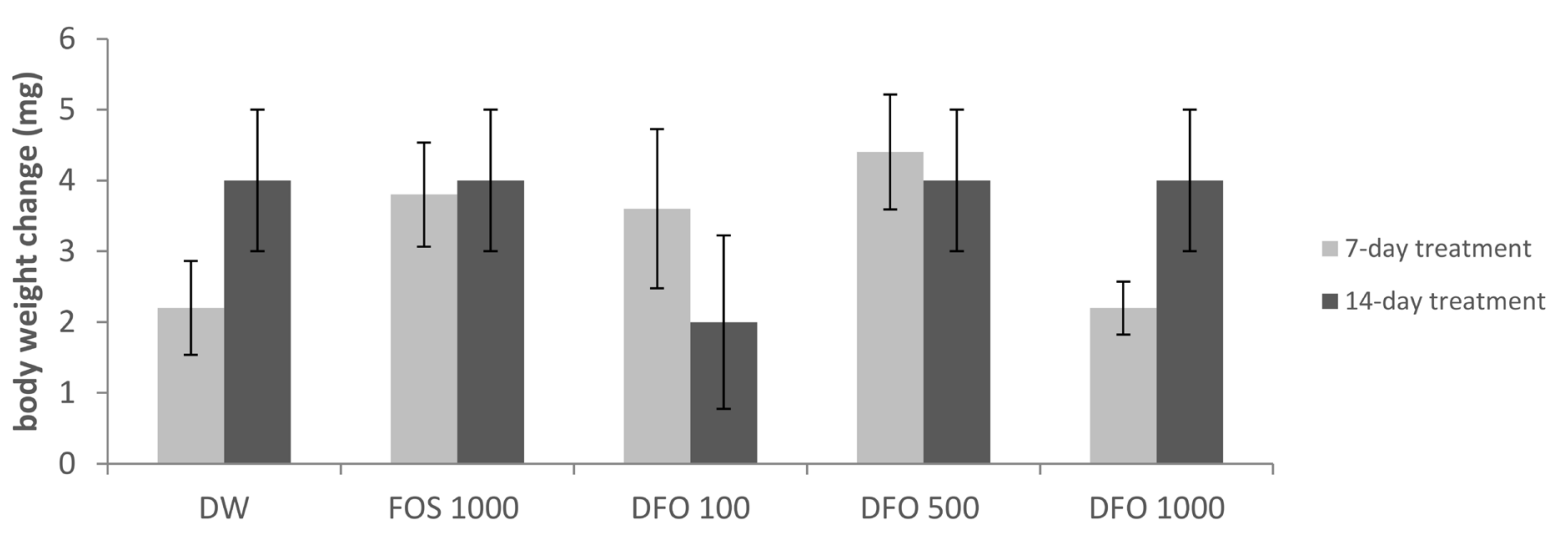

FIGURE 1. Body weight and body weight change of mice treated with DW, DFO and FOS for 7 and 14 days. Line graphs show the body weight of mice treated with DW, DFO and FOS for 7 days (A) and 14 days (B). Bar graphs show the body weight change of mice treated with DW, DFO and FOS for 7 and 14 days (C) 
A

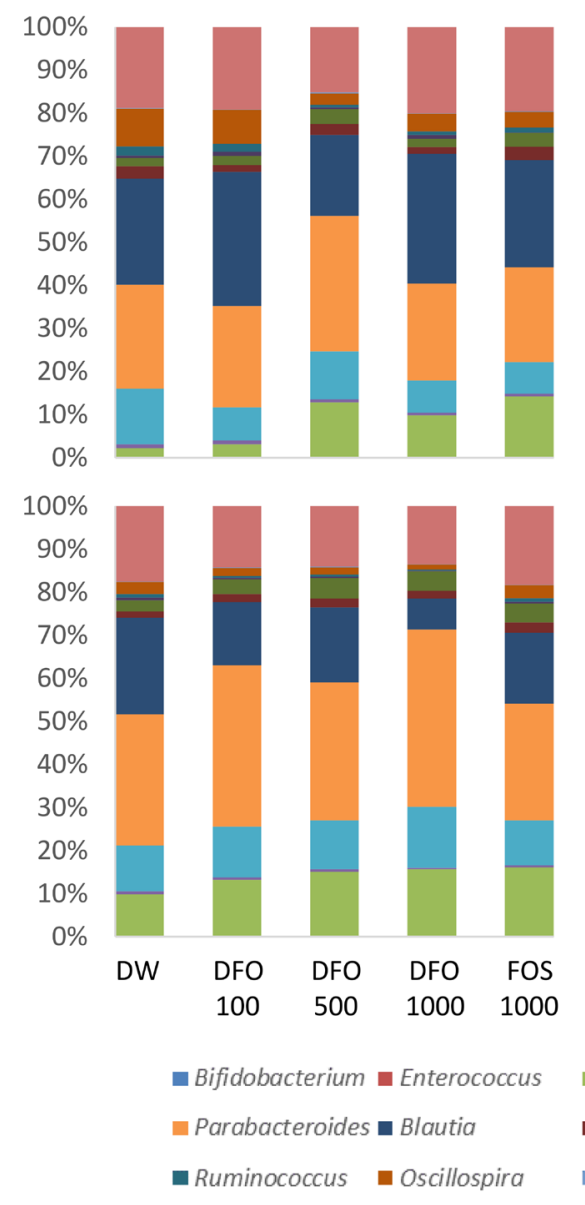

B

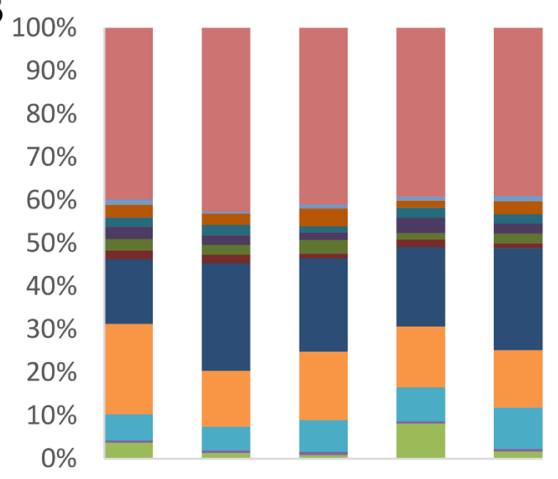

D $100 \%$

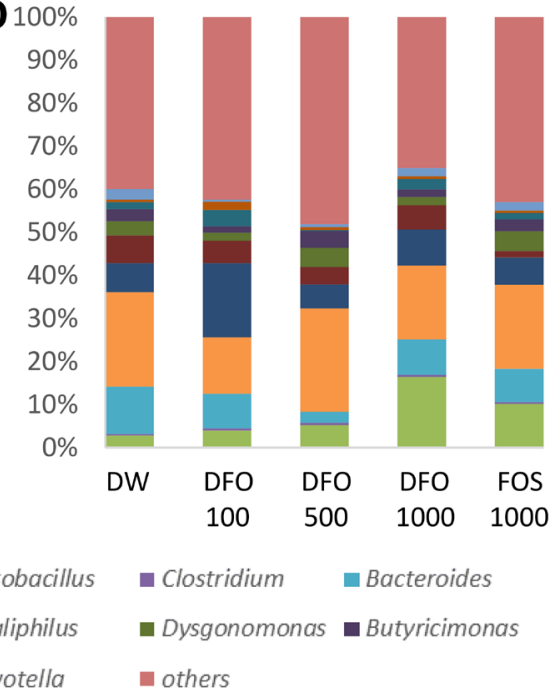

FIGURE 2. The composition and relative OTU abundance of microbiota. Bar graphs show composition and relative OTU abundance of microbiota in the proximal colon of mice treated with DW, DFO and FOS for 7 days (A) and 14 days (B), and in the distal colon of 7-day-treatment mice (C) and 14-day-treatment mice (D)

2.516 to 2.625 and from 0.136 to 0.168 , which were not dissimilar to the indices of the 7-day treatment groups. The evenness of bacteria ranged from 0.450 to 0.466 . There was also a considerable increase in populations of other bacteria in the proximal colon at the end of 14-day treatments.

In the distal colon, Blautia (7 - 22\%), Parabacteroides (27 - $41 \%)$, Bacteroides (10 - $14 \%)$ and Lactobacillus $(9$ $-16 \%$ ) were the dominant bacteria in the 7-day treatment groups (Figure 2(C)). The OTU richness of bacteria in distal colon of mice from the 7-day treatment groups DW, DFO100, DFO500, DFO1000, and FOS1000 were 311, 246, 281, 261, and 295 OTUs, respectively (Table 2). The Shannon-Weiner diversity indices ranged from 2.054 to 2.486 while Simpson diversity indices ranged from 0.144 to 0.225 . The range of evenness of bacteria in all the 7-day treatment groups was from 0.369 to 0.437 .

Bacterial dominance in the distal colon of mice treated for 14 days showed a similar profile to that of mice treated for 7 days (Blautia (6 - $17 \%$ ), Parabacteroides (13 - 22 $\%$ ), Bacteroides (3 - $11 \%$ ), and Lactobacillus (3 - 16\%)) (Figure 2(D)) but the proportion of other bacteria considerably increased in the distal colon of mice treated for 14 days. The total OTU richness at genus level in the distal colon of the 14-day treatment groups DW, DFO100, DFO500, and DFO1000, and FOS1000 were 234, 269, 262, 264, and 289 OTUs, respectively (Table 2). The Shannon-Wiener and Simpson diversity indices of the 14day treatment groups were $2.343-2.726$ and $0.120-0.197$, respectively. The evenness of bacteria was similar in all treatments $(0.421-0.487)$.

\section{QUANTITIES OF TOTAL BACTERIA, BIFIDOBACTERIA, LACTOBACILLI AND ENTEROCOCCI}

The qPCR results showed that total bacteria in the proximal colon of mice treated for 7 days was approximately $10^{9}$ $10^{10}$ cells/mg DNA, while total bacteria in the distal colon of these mice was approximately $10^{10}-10^{11}$ cells/mg DNA (Figure 3(A) and 3(B)). The numbers of total bacteria in the proximal and distal colon of mice treated for 7 days were not significantly different from the control $(p>0.05)$. The numbers of total bacteria in both proximal and distal colons of mice treated with DFO and FOS for 14 days were also not significantly different from the control (approximately $10^{10}-10^{11}$ cells/mg DNA) $(\mathrm{p}>0.05$, Figure 3(C) and 3(D)). 
TABLE 2. OTU richness, evenness, Shannon-Weiner and Simpson diversity indices of microbiota in proximal and distal colon of mice treated with DW, DFO and FOS for 7 days and 14 days

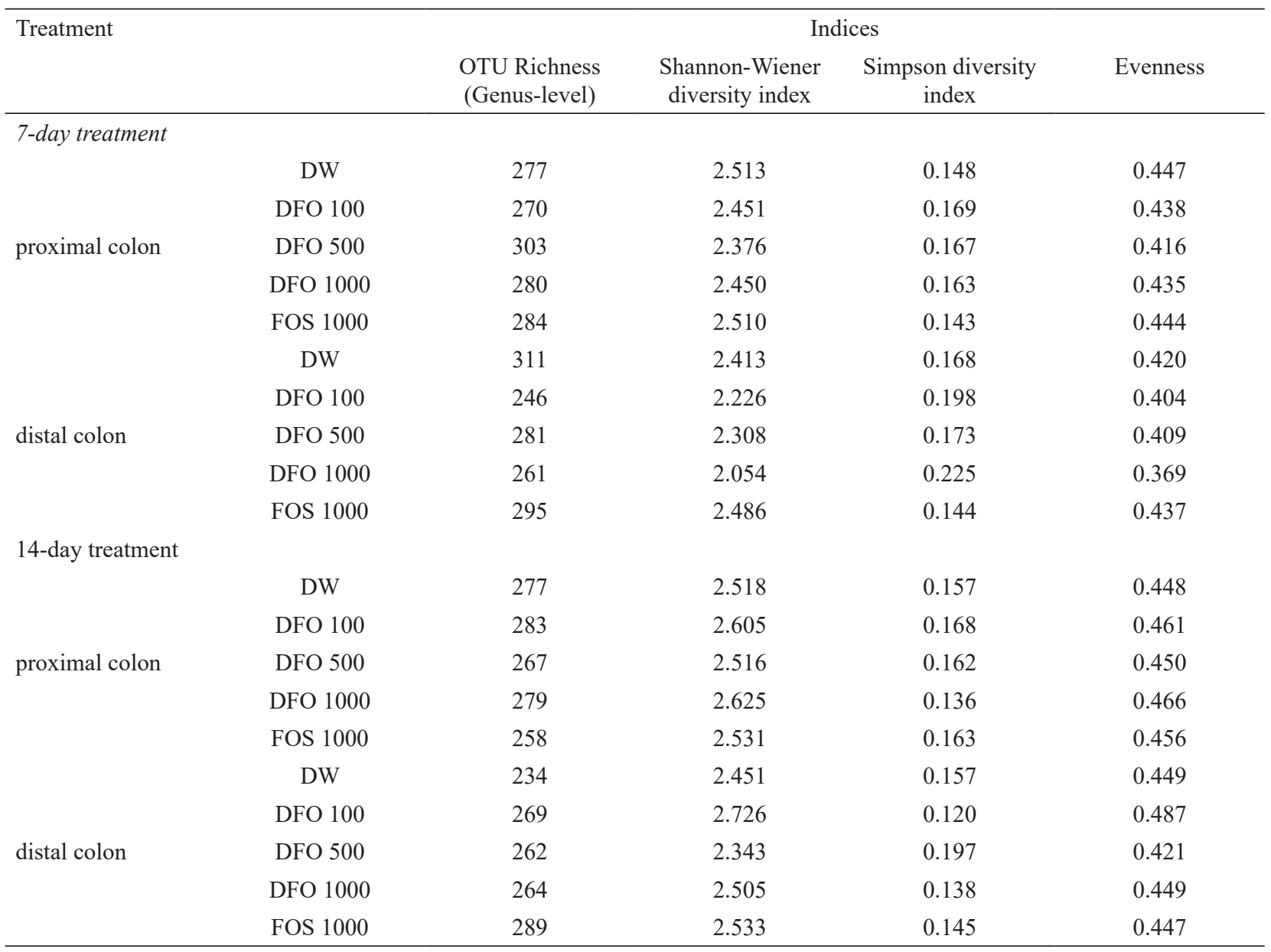

The concentration of Bifidobacteria in the proximal colon of mice treated with DFO and FOS for 7 and 14 days were approximately $10^{7}-10^{8}$ cells/mg DNA (Figure 3(E) and $3(\mathrm{~F}))$. These numbers were not significantly different from the control $(p>0.05)$. Similarly, in the distal colon of mice treated with DFO and FOS for 7 days, the number of Bifidobacteria was not significantly different from the control (Figure 3(G)). However, in the 14-day treatment groups DFO100 $\left(6.69 \pm 0.90 \times 10^{8}\right.$ cells $/ \mathrm{mg}$ DNA $)$ and DFO1000 $\left(4.85 \pm 1.64 \times 10^{8}\right.$ cells $/ \mathrm{mg}$ DNA $)$, the concentration of Bifidobacteria in the distal colon was significantly higher than the control $\left(7.27 \pm 3.25 \times 10^{7}\right.$ cells/mg DNA) (Figure 3(H)).

Lactobacilli in the proximal colon of mice treated with DFO500 for 7 days $\left(2.23 \pm 0.61 \times 10^{9}\right.$ cells $/ \mathrm{mg}$ DNA $)$ was slightly higher than the control $\left(5.88 \pm 4.96 \times 10^{7}\right.$ cells $/$ mg DNA) $(\mathrm{p}<0.05$, Figure $3(\mathrm{I}))$ but the number of Lactobacilli in the proximal colon of all 14-day treatment groups was not significantly different from the control ( $p$ $>0.05$, Figure $3(\mathrm{~J})$ ). In the distal colon of mice treated for 7 and 14 days, Lactobacilli numbers were not significantly different from the control ( $\mathrm{p}>0.05$, Figure $3(\mathrm{~K})$ and $3(\mathrm{~L})$ ).

In this study, numbers of Enterococci were significantly lower in the proximal colon of mice from the 14-day treatment groups DFO100, DFO500, DFO1000, and FOS1000 $(\mathrm{p}<0.05$, Figure $3(\mathrm{~N}))$. However, no reduction occurred in the proximal colon of mice in the 7-day treatment groups DFO100, DFO500, DFO1000, and FOS1000 ( $>>0.05$, Figure 3(M)). Numbers of Enterococci in the distal colon of mice treated for 7- and 14-days were not different from the control (Figure $3(\mathrm{O})$ and $3(\mathrm{P})$ ).

\section{DISCUSSION}

The effects of prebiotic DFO on gut microbiota in the proximal and distal colon of mice were investigated. The results showed that DFO did not affect the body weight of the mice, but could change the composition of microbiota in the proximal and distal colon. The V3-V4 hypervariable region of the bacterial $16 \mathrm{~S}$ rRNA gene was sequenced by Illumina-Miseq. Blautia, Parabacteroides, Bacteroides. and Lactobacillus were the dominant bacteria in both proximal and distal colons. Blautia made up the highest proportion of microbiota in the proximal colon, whereas in the distal colon Parabacteroides was dominant. These commensal bacteria are commonly found in the human and rodent gut (Rezzonico et al. 2011; Salminen et al. 1998). 

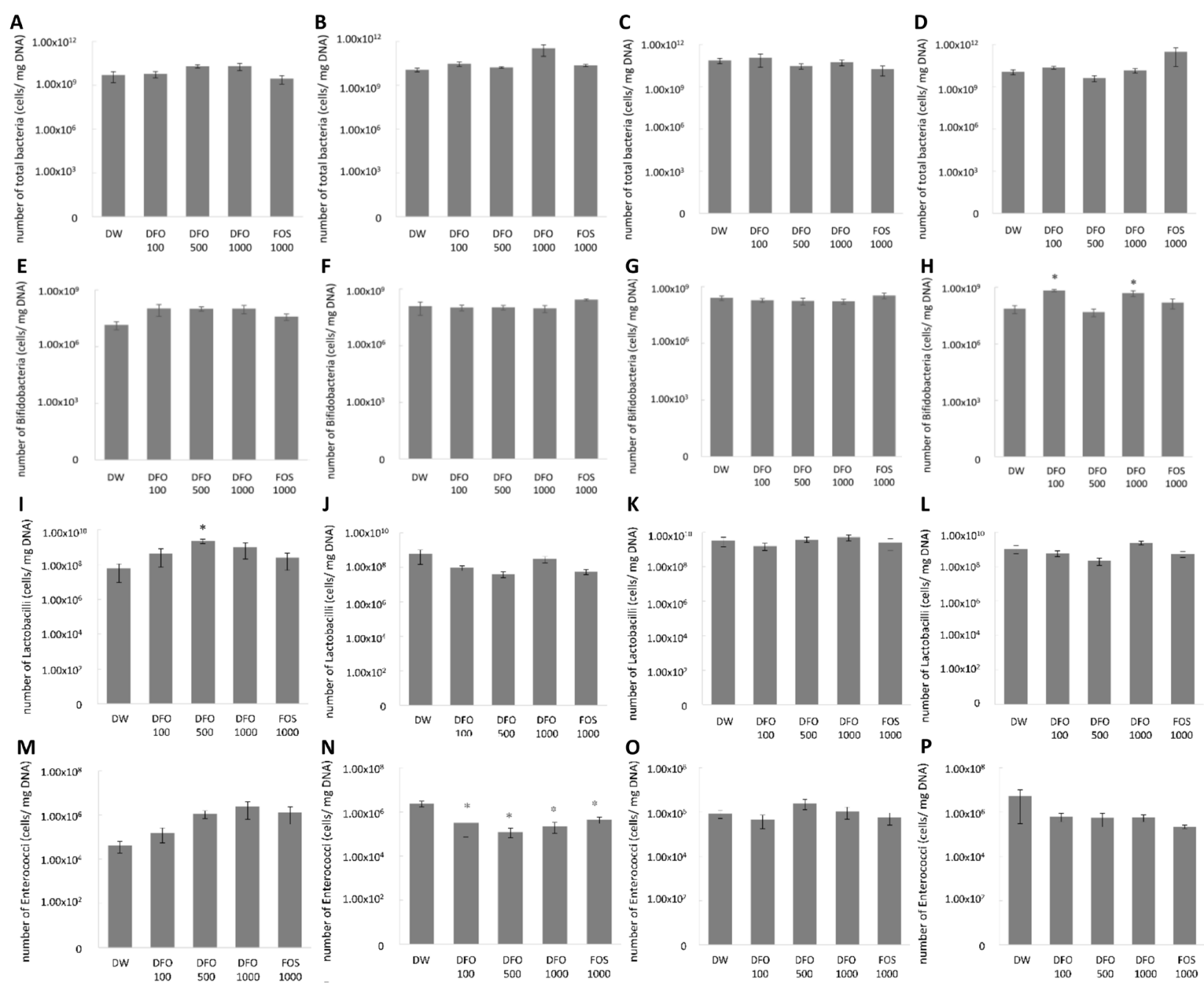

FIGURE 3. The bar graphs show the numbers of bacteria present in the colons of treated mice: Total bacteria in the proximal colon of mice treated with DW, DFO and FOS for 7 days (A) and 14 days (B), and in distal colon of 7-day-treatment mice (C) and 14-day-treatment mice (D); Bifidobacteria in the proximal colon of mice treated with DW, DFO and FOS for 7 days (E) and 14 days $(\mathrm{F})$, and in the distal colon of 7-day-treatment mice $(\mathrm{G})$ and 14-day-treatment mice $(\mathrm{H})$; Lactobacilli in the proximal colon of mice treated with DW, DFO and FOS for 7 days (I) and 14 days (J), and in the distal colon of 7-day-treatment mice (K) and 14-day-treatment mice (L); Enterococci in the proximal colon of mice treated with DW, DFO and FOS for 7 days (M) and 14 days $(\mathrm{N})$, and in the distal colon of 7-day-treatment mice $(\mathrm{O})$ and 14-day-treatment mice $(\mathrm{P})$. Asterisks above the bars indicate significant differences from control (Tukey's honestly significant difference test, $\mathrm{p}<0.05$ )

To compare the bacteria of interest, we conducted qPCR to estimate the number of total bacteria, Bifidobacteria, Lactobacilli, and Enterococci. We found that Bifidobacteria tended to increase in the distal colon of mice treated with $100 \mathrm{mg} / \mathrm{kg}$, and $1000 \mathrm{mg} / \mathrm{kg}$ DFO for 14 days. The amount of Lactobacilli also increased in the proximal colon of mice that received $500 \mathrm{mg} / \mathrm{kg}$ DFO for 7 days. These results suggest that DFO was utilized by Bifidobacteria and Lactobacilli, and enhanced their growth. This result was consistent with an in vitro study, which showed that DFO stimulated the growth of Bifidobacteria and Lactobacilli (Dasaesamoh et al. 2016a; Wichienchot et al. 2010). Fermentation products of Bifidobacteria and Lactobacilli include acetate, lactate, formate, and ethanol (Salminen et al. 1998). Formate and acetate are short-chain fatty acids, which are also energy sources for the host's intestinal cells that in turn benefit the host's health (Binn 2013).

In the case of Enterococci, growth decreased in the proximal colon of mice treated with DFO100, DFO500, DFO1000, and FOS1000 for 14 days. Both DFO and FOS effectively depleted numbers of Enterococci. Most Enterococci found in the human colon are Enterococcus faecalis and Enterococcus faecium that act as commensal bacteria in the host (Gilmore et al. 2002). However, Enterococcus faecalis can cause infection and harmful effects when the population increases. Enterococcus faecalis infections increase in patients suffering from inflammatory bowel disease (IBD) (Zhou et al. 2016). In this study, we used healthy mice to test the effects of DFO on the composition of gut microbiota. Although there was growth of Enterococci as commensal bacteria, its growth 
was controlled by the other normal flora and therefore caused no serious illness in the mice. For further experiment, the IBD model with Enterococcus faecalis infection might be included to investigate and confirm that DFO can protect the host from harmful bacteria. The immunity of treated mice should also be observed to support the hypothesis that DFO balances microbiota to the benefit of the host's health.

\section{CONCLUSION}

This study suggests that DFO has the ability to modulate the microbial composition in both the proximal and distal colons of mice. DFO treatment could also change the proportion of Lactobacilli and Enterococci in the proximal colon, and that of Bifidobacteria in the distal colon. Even though this study was carried out with healthy mice, the results showed that DFO efficiently increased the growth of beneficial bacteria (Bifidobacteria and Lactobacilli) in the colon while depleting the numbers of harmful bacteria, like Enterococci.

\section{ACKNOWLEDGEMENTS}

This work was supported by Research and Development Office, Prince of Songkla University under PSU General Grant [Grant number SCI590683S]. We would like to thank Assoc. Prof. Santad Wichienchot for his assistance in preparing DFO powder in this study and Fittree Hayeeawaema for helping us with tissue collection. We also thank Wichuda McConnell and Thomas Duncan Coyne for proofreading this manuscript.

\section{REFERENCES}

Ariffin, A.A., Bakar, J., Tan, C.P., Rahman, R.A., Roselina, K. \& Loi, C.C. 2008. Essential fatty acids of pitaya (dragon fruit) seed oil. Food Chem. 114: 561-564.

Awad, W., Ghareeb, K. \& Böhm, J. 2008. Intestinal structure and function of broiler chickens on diets supplemented with a synbiotic containing Enterococcus faecium and oligosaccharides. Int. J. Mol. Sci. 9: 2205-2216.

Binn, N. 2013. Role of the GI tract microbiota in health and disease. In Probiotics, Prebiotics and the Gut Microbiota, edited by Gibson, G.R. Brussels, Belgium: International Life Science Institute Europe. pp. 4-10.

Charoensiri, R., Kongkachuichai, R., Suknicom, S. \& Sungpuag, P. 2009. Beta-carotene, lycopene, and alpha-tocopherol contents of selected Thai fruits. Food Chem. 113: 202-207.

Dasaesamoh, R., Youravong, W. \& Wichienchot, S. 2016a. Digestibility, fecal fermentation and anti-cancer of dragon fruit oligosaccharides. Int. Food Res. J. 23: 2581-2587.

Dasaesamoh, R., Youravong, W. \& Wichienchot, S. 2016b. Optimization on pectinase extraction and purification by yeast fermentation of oligosaccharides from dragon fruit (Hylocereus undatus). Int. Food Res. J. 23: 2601-2607.

Femia, A.P., Salvadori, M., Broekaert, W.F., Francois, I.E.J.A., Delcour, J.A., Courtin, C.M. \& Caderni, G. 2010. Arabinoxylan-oligosaccharides (AXOS) reduce preneoplastic lesions in the colon of rats treated with 1,2-dimethylhydrazine (DMH). Eur. J. Nutr. 49: 127-132.
Fu, C.J., Carter, J.N., Li, Y., Porter, J.H. \& Kerley, M.S. 2006. Comparison of agar plate and real-time PCR on enumeration of Lactobacillus, Clostridium perfringens and total anaerobic bacteria in dog faeces. Lett. Appl. Microbiol. 42: 490-494.

Gibson, G.R. \& Rastall, R.A. 2006. Prebiotics: Development and Application. West Sussex, England: John Wiley \& Sons Press.

Gibson, G.R. \& Roberfroid, M.B. 1995. Dietary modulation of the human colonic microbiota: Introducing the concept of prebiotics. J. Nutr. 125: 1401-1412.

Gibson, G.R., Scott, K.P., Rastall, R.A., Tuohy, K.M., Hotchkiss, A., Dubert-Ferrandon, A., Gareau, M., Murphy, E.F., Saulnier, D., Loh, G., Macfarlane, S., Delzenne, N., Ringel, Y., Kozianowski, G., Dickmann, R., Lenoir-Wijnkook, I., Walker, C. \& Buddington, R. 2010. Dietary prebiotics: Current status and new definition. Food Sci. Technol. Bull. Funct. Foods 7: 1-19.

Gilmore, M.S., Clewell, D.B., Courvalin, P., Dunny, G.M., Murray, B.E. \& Rice, B.L. 2002. The Enterococci: Pathogenesis, Molecular Biology, and Antibiotic Resistance. Washington: ASM Press.

Guarner, F. \& Malagelada, J.R. 2003. Gut flora in health and disease. Lancet 361: 512-519.

He, J.H. \& Jiang, S. 2005. Quantification of enterococci and human adenoviruses in environmental samples by real-time PCR. Appl. Environmantal Microbiol. 71: 2250-2255.

Johnston, D., Earley, B., Cormican, P., Murray, G., Kenny, D.A., Waters, S.M., McGee, M., Kelly, A.K. \& McCabe, M.S. 2017. Illumina MiSeq 16S amplicon sequence analysis of bovine respiratory disease associated bacteria in lung and mediastinal lymph node tissue. BMC Vet. Res. 13: 1-18.

Kaufmann, P., Pfefferkorn, A., Teuber, M. \& Meile, L. 1997. Identification and quantification of Bifidobacterium species isolated from food with genus-specific. Appl. Environmantal Microbiol. 63: 1268-1273.

Mandal, V., Sen, S.K. \& Mandal, N.C. 2009. Effect of prebiotics on bacteriocin production and cholesterol lowering activity of Pediococcus acidilactici LAB 5. World J. Microbiol. Biotechnol. 25: 1837-1847.

Matsuki, T., Watanabe, K., Fujimoto, J., Takada, T., Matsumoto, K. \& Kado, Y. 2004. Quantitative PCR with 16S primers for analysis of human intestinal bifidobacteria. Appl. Environ. Microbiol. 70: 167-173.

Pan, X., Chen, F., Wu, T., Tang, H. \& Zhao, Z. 2009. Prebiotic oligosaccharides change the concentrations of short chain fatty-acids and the microbial population of mouse bowel. $J$. Zhejiang Univ. Sci. B 10: 258-263.

Patel, S. \& Goyal, A. 2012. The current trends and future perspectives of prebiotics research: A review. 3 Biotech. 2: 115-125.

Peerakietkhajorn, S., Tsukada, K., Kato, Y., Matsuura, T. \& Watanabe, H. 2015. Symbiotic bacteria contribute to increasing the population size of a freshwater crustacean, Daphnia magna. Environ. Microbiol. Rep. 7: 364-372.

Pelicano, E.R.L., Souza, P.A., Souza, H.B.A., Figueiredo, D.F., Boiago, M.M., Carvalho, S.R. \& Bordon, V.F. 2005. Intestinal mucosa development in broiler chickens fed natural growth promoters. Brazilian J. Poult. Sci. 7: 221229.

Rezzonico, E., Mestdagh, R., Delley, M., Combremont, S., Dumas, M.E., Holmes, E., Nicholson, J. \& Bibiloni, R. 2011. Bacterial adaptation to the gut environment favors successful colonization: Microbial and metabonomic 
characterization of a simplified microbiota mouse model. Gut. Microbes 2: 307-318.

Sabater-Molina, M., Larque, E., Torrella, F. \& Zamora, S. 2009. Dietary fructooligosaccharides. Ovid. Medlin. Physiol. Biochem. 65: 315-328.

Salminen, S., Bouley, C., Boutron, M.C., Cummings, J.H., Franck, A., Gibson, G.R., Isolauri, E., Moreau, M.C., Roberfroid, M. \& Rowland, I. 1998. Functional food science and gastrointestinal physiology and function. $\mathrm{Br} . J$. Nutr. 80: S147.

Thammarutwasik, P., Hongpattarakere, T., Chantachum, S., Kijroongrojana, K., Itharat, A., Reanmongkol, W., Tewtrakul, S. \& Ooraikul, B. 2009. Prebiotics - A review. Songklanakarin J. Sci. Technol. 31: 401-408.

The R Core Team. 2013. $R$ : A language and Environment for Statistical Computing. R Foundation for Statistical Computing, Vienna, Austria.

Vamanu, E. \& Vamanu, A. 2010. The influence of prebiotics on bacteriocin synthesis using the strain Lactobacillus paracasei CMGB16. African J. Microbiol. Res. 4: 534-537.

Wichienchot, S., Jatupornpipat, M. \& Rastall, R.A. 2010. Oligosaccharides of pitaya (dragon fruit) flesh and their prebiotic properties. Food Chem. 120: 850-857.

Wichienchot, S. \& Pansai, N. 2013. Prebiotic dragon fruit oligosaccharide for elderly. Research Report, Prince of Songkla University, Songkhla, Thailand.

Xu, B., Wang, Y., Li, J. \& Lin, Q. 2009. Effect of prebiotic xylooligosaccharides on growth performances and digestive enzyme activities of allogynogenetic crucian carp (Carassius auratus gibelio). Fish Physiol. Biochem. 35: 351-357.

Yeo, S.K. \& Liong, M.T. 2010. Effect of prebiotics on viability and growth characteristics of probiotics in soymilk. J. Sci. Food Agric. 90: 267-275.
Zhou, Y., Chen, H., He, H., Du, Y., Hu, J., Li, Y., Li, Y., Zhou, Y., Wang, H., Chen, Y. \& Nie, Y. 2016. Increased Enterococcus faecalis infection is associated with clinically active Crohn disease. Medicine 95: 39.

Saranya Peerakietkhajorn*, Nilobon Jeanmard, Papatsorn Chuenpanitkit, Sakena K-da \& Kanrawee Bannob

Department of Biology

Faculty of Science

Prince of Songkla University

Hat Yai, Songkhla, 90110

Thailand

Sakena K-da, Kanrawee Bannob \& Pissared Khuituan Department of Physiology

Faculty of Science

Prince of Songkla University

Hay Yai, Songkhla, 90110

Thailand

Saranya Peerakietkhajorn*, Nilobon Jeanmard, Papatsorn Chuenpanitkit, Sakena K-da \& Pissared Khuituan

Gut Biology and Microbiota Research Unit

Prince of Songkla University

Hat Yai, Songkhla, 90110

Thailand

*Corresponding author; email: saranya.pe@psu.ac.th

Received: 19 April 2019

Accepted: 18 November 2019 
